\title{
Diplomasi Bencana Alam sebagai Saran Meningkatkan Kerjasama Internasional
}

\section{Ratih Herningtyas dan Surwandono}

Jurusan IImu Hubungan Internasional, Fakultas IImu Sosial dan Politik Universitas Muhammadiyah Yogyakarta

Ringroad Barat Tamantirto, Kasihan, Bantul 55183

Email: ratih_herningtyas@umy.ac.id

\begin{abstract}
This paper aims to examine how the issue of disasters in Indonesia can be modified into a positive social capital to solve social, economic, political and social culture's problems in disaster prone areas. Indonesia is very vulnerable to natural disasters. Some of the latest and most destructive natural disasters are the earthquake followed by tsunami that hit Aceh Indonesia on 2004, earthquake hit Yogyakarta and Central Java earthquake on 2006 and volcanic eruption of Mount Merapi Yogyakarta and Central Java 2011. Using qualitative approach, this paper found that Indonesia's disaster managements get worldwide recognition and increases Indonesia's competitiveness toward other countries. These recognitions become the sources of Indonesia's soft power, and can be used as a strategic instrument to build international cooperation and collaboration.

Keywords: natural disaster, cooperation, disaster diplomacy
\end{abstract}

\begin{abstract}
Abstrak
Tulisan ini bertujuan untuk mengkaji bagaimana isu bencana di Indonesia dapat dimodifikasi menjadi modal sosial untuk menyelesaikan masalah sosial, ekonomi, politik dan sosial budaya di daerah rawan bencana. Indonesia sangat rentan dengan bencana. Beberapa bencana terakhir dan paling menghancurkan adalah gempa bumi disusul tsunami yang terjadi di Aceh pada 2004, gempa bumi di Yogyakarta dan Jawa tengah pada 2006, dan erupsi merapi di Gunung Merapi dan Jawa Tengah pada 2011. Menggunakan pendekatan kualitatif, tulisan ini menemukan bahwa manajeman bencana Indonesia mendapat pengakuan dunia dan meningkatkan kompetitif Indonesia terhadap negara lain. Pengakuan ini menjadi sumber soft power Indonesia dan dapat digunakan sebagai strategi untuk membangun kerjasama dan kolaborasi internasional.

Kata Kunci: bencana alam, kerjasama, diplomasi bencana.
\end{abstract}

\section{PENDAHULUAN}

Indonesia adalah negara yang secara faktual sangat rawan oleh terjadinya bencana alam. Dalam laporan UNISDR (United Nations International Strategy for Disaster Reduction), sebagai sebuah badan PBB yang menangani perihal strategi penanggulangan bencana global, pada tahun 2010 mempublikasikan "The Asia Pacific Disaster Report 2010”, disebutkan bahwa Indonesia adalah negara dengan jumlah korban meninggal akibat bencana alam kedua terbesar di Asia Pasifik, dalam rentang waktu 20 tahun terakhir sebanyak
191.164 jiwa (The Asia Pacific Disaster Report, 2010:5). Selain itu, dalam laporan ini juga dipaparkan estimasi kerugian ekonomi yang diderita Indonesia mencapai US\$22,5 miliar. Lebih jauh lagi Bappenas dalam laporannya juga melansir bahwa bencana alam di Indonesia hingga tahun 2007 saja telah menimbulkan pengeluaran pemerintah sebesar US\$12 triliun, atau sekitar Rp. 110 triliun (Bappenas, 2007: 23).

Angka ini setara dengan 3,1\% dari total PDB Indonesia pada tahun 2007 atau setara dengan 15,8\% 
dari APBN 2007. Dituturkan lebih lanjut dalam laporan tersebut, apabila bencana dengan skala massif seperti gempa bumi dan tsunami Aceh 2004 atau gempa bumi DIY 2006 terulang, maka pemerintah akan kewalahan secara ekonomi.

Bencana alam menjadi sesuatu yang tidak terhindarkan di Indonesia mengingat posisi Indonesia yang berada pada pertemuan 4 lempeng besar dunia yakni Lempeng Eurasia; Lempeng Australia; Lempeng Pasifik; dan Lempeng Filipina, sangat berpengaruh pada intensitas kebencanaan geologis di Indonesia. Adanya pertemuan lempeng-lempeng dunia yang terus aktif bergerak ini berimplikasi pada munculnya rantai kegunungapian yang melintang dari Sumatra, Jawa, Nusa Tenggara, Sulawesi, ke Maluku. Akibat aktivitas tektonik dan vulkanik ini bencana alam berupa gempa bumi, tsunami, letusan lava dan gas gunung api menjadi sering terjadi di Indonesia. Arnold, seorang peneliti geologis asal Amerika Serikat, menuliskan bahwa Indonesia adalah salah satu negara dengan tingkat kegempaan tertinggi di dunia, 10 kali lebih tinggi dibanding Amerika Serikat. (Arnold, dalam Bappenas, ibid: 15). Peneliti lain bernama Hamzah Latief menyebutkan bahwa selama kurun waktu tahun 1600-2000, terdapat 105 kejadian tsunami yang 90\% di antaranya disebabkan oleh gempa tektonik, 9\% oleh letusan gunung berapi dan $1 \%$ oleh tanah longsor (Latief, dalam Bappenas, ibid: 15).

Berdasarkan laporan Bappenas, wilayah pantai di Indonesia merupakan wilayah yang rawan terjadi bencana tsunami terutama pantai barat Sumatera, pantai selatan Pulau Jawa, pantai utara dan selatan pulau-pulau Nusa Tenggara, pulau-pulau di Maluku, pantai utara Irian Jaya, dan seluruh pantai di Sulawesi. Laut Maluku adalah daerah yang paling rawan tsunami. Dalam kurun waktu tahun 1600-2000, di daerah ini telah terjadi 32 tsunami, 28 di antaranya diakibatkan oleh gempa bumi dan 4 oleh meletusnya gunung berapi di bawah laut. Mulai dari bagian Barat Indonesia yaitu Pulau Sumatera, adalah tempat bertubruknya Lempeng Australia Barat dan Lempeng Eurasia yang membentuk Bukit Barisan. Daerah ini adalah daerah tektonik yang aktif sehingga rawan terhadap gempa bumi dan tsunami. Selain itu deretan gunung berapi aktif di Bukit Barisan ini juga menimbulkan potensi bencana vulkanik. Bencana geologis di Pulau Sumatra belum lama ini termasuk gempa bumi dan tsunami Aceh 2004, gempa bumi dan tsunami Nias 2005, gempa bumi Sumatera Barat 2009, gempa bumi dan tsunami Mentawai 2010, dan letusan Gunung Sinabung 2013. BMKG sendiri telah mengingatkan bahwa ancaman gempa megathrust kemungkinan akan terjadi tidak lama lagi di Kepulauan Mentawai dengan magnitude yang massif.

Selanjutnya topografi Pulau Jawa sendiri juga banyak memiliki patahan tektonik dengan gunung api yang sangat banyak. Patahan ini adalah kelanjutan dari patahan di Sumatera. Adanya Palung Jawa tepat di selatan pantai Pulau Jawa juga menjadi bukti adanya aktivitas tektonik di wilayah ini. Kemudian, gununggunung berapi di Pulau Jawa juga sangat aktif. Gunung Merapi di Daerah Istimewa Yogyakarta dianggap sebagai salah satu gunung berapi teraktif di dunia. Sementara itu Gunung Krakatau dan Gunung Kelud pernah meletus dan menimbulkan korban jiwa yang besar di masa lalu. Bencana geologis terakhir di Pulau Jawa antara lain meletusnya Gunung Merapi 2006; 2010; dan 2013, gempa bumi DIY 2006, gempa bumi Pangandaran 2006, gempa bumi Tasikmalaya 2009, gempa bumi Cilacap 2011, meletusnya Gunung Kelud 2014, dan meletusnya Gunung Slamet 2014. Pulau Jawa adalah wilayah terekspos bencana alam tertinggi mengingat kondisi tektonik dan vulkanik yang rawan, curah hujan yang tinggi, kepadatan penduduk, bangunan kota rapat yang masih belum aman gempa, dan kurangnya daerah resapan air termasuk hutan.

Sedangkan wilayah Pulau Bali yang masih berada di utara jalur Java Megathrust juga mengalami gempa bumi pada 2011 lalu. Untuk wilayah Indonesia Timur gempa yang memakan korban jiwa juga terjadi di Nabire, Papua 2004 silam. Remukan hasil tubrukan antara Lempeng Eurasia dan Lempeng Australia yang membangun sabuk Sunda Megathrust (Andaman Megathrust, Sumatra Megathrust, dan Java Megathrust) akan menjadi sumber utama terjadinya bencana geologis terutama di Sumatera, Jawa, dan sekitarnya. 
Bencana hidro-meteorologi juga menjadi permasalahan lain dari kebencanaan alam di Indonesia, walaupun tidak menimbulkan korban sebanyak bencana geologis. Indonesia yang beriklim muson tropis dengan curah hujan tinggi sangat rentan oleh bencana hidro-meteorologi. Dalam tulisan mantan Menteri Kesejahteraan Sosial Indonesia, Bachtiar Chamsyah, bencana hidro-meteorologi menyumbang 53,3\% dari keseluruhan persentase bencana tercatat yang berjumlah 1.429 dalam dua tahun saja, antara 2003-2005 (Chamsyah, 2007:1). Curah hujan yang mendadak begitu tinggi pada daerah yang tidak memiliki tanah resapan air yang baik, atau di area luapan sungai dapat menimbulkan banjir yang banyak merugikan secara material. Daerah seperti Jakarta, Surabaya, Medan, dan tepi sungai-sungai besar di Indonesia sering menjadi langganan banjir yang mematikan roda perekonomian berhari-hari. Bencana hidro-meteorologi lain yang cukup sering terjadi adalah angin ribut, tanah longsor dan kekeringan.

Dari semua bencana alam di Indonesia semenjak 15 tahun terakhir hanya gempa bumi dan tsunami Aceh 2004 yang ditetapkan pemerintah sebagai "bencana nasional". Hal ini dikarenakan baik Pemkab, Pemkot, dan Pemprov Aceh sudah tidak mampu menangani bencana dengan skala massif ini, dengan lebih dari 180.000 korban jiwa dan kerugian ekonomi di atas Rp. 45 trilyun.

Sebagai akibat dari besarnya potensi bencana alam yang mungkin terjadi, jumlah korban yang cenderung besar, serta kerugian material akibat terjadinya bencana alam, masyarakat cenderung menganggap bencana alam sebagai sebuah peristiwa yang membawa konsekuensi negatif bagi kehidupan mereka, seperti kehilangan anggota keluarga, harta benda dan kehilangan kehidupan sosial yang telah mereka bangun bertahuntahun. Pemaknaan secara negatif terhadap bencana alam berkorelasi terhadap pemaknaan mereka terhadap kondisi geografis dan topografis yang rawan bencana alam, yang justru akan melahirkan sikap dan kebijakan yang lari dari kenyataan dan realitas kehidupan. Realitas ini mendorong pemerintah sebagai pemegang kekuasaan tertinggi negara untuk berperan lebih besar dalam upaya antisipasi dan penanggulangan bencana di Indonesia.

Selain itu, diperlukan sebuah meassure dalam kerangka pelembagaan pencegahan, mitigasi, respon, dan rekonstruksi bencana alam yang sistematis. Pelembagaan ini melibatkan banyak pihak baik secara nasional maupun internasional, dan kerjasama diantara keduanya diperlukan baik secara teknis maupun politis. Hal yang menarik adalah, studi kontemporer menunjukkan bahwa bencana alam dipahami tidak sepenuhnya destruktif. Ada banyak hikmah yang dapat ditarik dari kemunculan bencana alam, apabila dikelola dengan meassure yang tepat, bahkan bencana ini dapat dikapitalisasi lebih lanjut dalam bentuk disaster diplomacy.

\section{METODOLOG}

\section{DIPLOMASI BENCANA ALAM: SEBUAH KERANGKA ANALISIS}

Ilan Kelman sebagai akademisi yang banyak sekali mengadvokasi pengimplementasian disaster diplomacy atau diplomasi bencana alam, cenderung membedakan dua konsep antara natural hazard dan natural disaster (I. Kelman, 2007: 6). Fenomena bencana alam dalam bentuk hazard tidak akan menjadi disaster, dalam pengertian tidak akan berdampak destruktif, jika upaya pencegahan dan kesiapan termasuk secara teknis serta politis dilakukan dengan baik. Kalaupun disaster tidak dapat dihindari lagi, maka fenomena tersebut jika dikelola dengan baik dapat menjadi kapital yang justru menguntungkan daerah atau negara terdampak bencana alam. Diplomasi bencana alam bekerja dalam sudut pandang pemikiran ini. Peluang dapat muncul dari pengaruh krisis, dan krisis sendiri dapat menjadi sebuah peluang yang bermakna.

Dalam definisi literatur sebenarnya diplomasi bencana alam dipahami sebagai studi tentang bagaimana dan mengapa bencana alam berkontribusi terhadap atau tidak terhadap perdamaian atau konflik, yang diteliti sebelum dan setelah sebuah bencana.

Dalam konteks sebelum bencana, diplomasi ini berbicara tentang pencegahan, mitigasi, dan upaya untuk mengurangi jatuhnya korban jiwa. Dalam 
konteks setelah bencana, diplomasi ini berbicara tentang bagaimana konflik dan perdamaian dipengaruhi oleh bencana alam. Bagian kedua dari definisi diplomasi bencana alam adalah adagium "jika kita tidak menghendaki kejadian ini, kita harus berusaha mencari peluang untuk mengubah situasinya”. UN-ISDR memaparkan bahwa, diplomasi bencana alam mengeksplorasi bagaimana dan mengapa pengurangan dampak bencana, baik selama prabencana termasuk pencegahan dan mitigasi, dan pascabencana termasuk respon dan pemulihan, berkontribusi atau tidak berkontribusi bagi kerjasama dan perdamaian (UN-ISDR Informs, 2007: 54). Kelman lebih lanjut menjelaskan diplomasi bencana alam berdiskusi tentang peran dari aktivitas terkait bencana alam tidak hanya dalam hubungan internasional, namun juga dalam konflik politik dalam sebuah negara merdeka (Geoforum, 2008: 511-26). Diplomasi bencana alam berinteraksi dalam banyak variasi "bencana”, bukan hanya yang destruktif seperti gempa bumi dan ledakan industri, namun juga kejadian yang lebih luas seperti kekeringan, epidemik, dan perubahan iklim.

Konsep dan pemahaman bencana alam ini, akan dapat disinergikan dengan isu lokal dan nasional sebagai bagian dari soft diplomacy yang menopang kerjasama saling menguntungkan dengan berbagai pihak dalam lingkup luas. Diplomasi bencana alam dapat diaplikasikan dalam hubungan intra-negara maupun antar-negara. Namun perlu juga diketahui bahwa riset dan sejarah menunjukkan kecenderungan aktivitas terkait bencana alam, belum pernah menimbulkan diplomasi yang sifatnya baru, akan tetapi dapat menjadi katalis dan pendukung bagi diplomasi yang telah berlangsung sebelumnya, baik itu kultural; hubungan ekonomi; atau negosiasi rahasia di antara konstituen. Bencana alam sendiri akan berdampak dalam interaksi kerjasama pada jangka waktu yang terbatas, sehingga diplomasi bencana alam memerlukan saling dukungan dengan upaya diplomasi lain, agar mewujudkan kapitalisasi yang subsisten.

Andrew J. Snyder menyebutkan bahwa diplomasi bencana alam tidak dapat dipungkiri sangat menguntungkan dalam interaksi internasional karena dengan terjadinya bencana alam negara dapat menilai bagaimana kebijakan rezim negara lain memberikan respon (A.J. Snyder, 2008: 9). Hubungan internasional juga seringkali mengalami stagnasi dalam lingkaran siklus balas membalas kebijakan, sehingga bencana alam yang datang tiba-tiba di suatu negara akan dipahami sebagai peluang untuk memulai lingkaran siklus baru berdasarkan kerjasama. Snyder menyebutkan bahwa Diplomasi bencana alam antar negara yang bertujuan untuk meningkatkan soft-power juga menjadi kajian yang menarik, karena soft-power dapat diraih sebagai hasil diplomasi bencana alam. Softpower sendiri adalah konsep yang dipopulerkan Joseph Nye, yang bermakna kemampuan suatu pihak untuk memperoleh kepentingannya tanpa dengan koersi atau paksaan (J. S. Nye, 2008: 29). Negara yang memilih soft-power sebagai basis kekuatan diplomasi, lebih menggantungkan pada kemampuannya untuk bekerjasama dalam mewujudkan tujuan. Strategi diplomasi ini ditelaah lebih efisien secara biaya daripada strategi "carrot and stick" yang berbasis paksaan. Negara yang banyak memberikan bantuan dalam penanganan bencana akan dihormati dan dituakan. Hal ini secara tidak langsung akan meningkatkan posisi tawar negara pemberi bantuan tersebut dalam interaksi internasional. Sementara itu timbal balik kerjasama yang saling menguntungkan sering muncul setelah diplomasi bencana alam dilakukan.

Kerangka kedua adalah Complex Adaptive System (J. Holland dalam L.K. Comfort, 2000: 277-94 dan I. Kelman, 2006: 215-40) yang dipaparkan baik oleh Louise K. Comfort maupun Kelman dapat diterapkan dalam diplomasi bencana alam. Model konseptual dari CAS sangat penting berperan untuk melakukan pengkajian terhadap proses perubahan daerah yang terancam potensi bencana atau yang telah mengalami distraksi akut akibat bencana. Model ini berfokus pada transisi pada perubahan sosial, ekonomi, dan politik daerah atau negara di mana bencana berlangsung. Sistem sosial daerah bencana disebutkan akan mengalami dampak perubahan mendadak dan 
gangguan akut akibat bencana pada derajat tertentu. Sistem sosial daerah bencana ini akan terus berubah dalam pembelajaran baru, dan melembaga secara otomatis ketika berinteraksi dengan lingkungan dan pihak-pihak baru. Konstraksi sosial dan ekonomi yang terjadi akan berdampak pada berkurangnya konsolidasi politik lokal. Apabila bencana alam terjadi pada daerah berkonflik politik, berbagai faktor penawaran kerjasama dari lawan politiknya akan mewujudkan kerangka perdamaian. Kemudian dua negara atau daerah yang mempunyai potensi dan pengalaman bencana serupa dapat terbuka dengan kerjasama pengurangan resiko bencana, riset dan pertukaran data kebencanaan, saling berganti memberi bantuan ketika bencana datang, yang pada akhirnya dapat membuka jalur-jalur kerjasama lain yang menguntungkan.

\section{HASIL DAN PEMBAHASAN}

Beberapa pakar menyebutkan bahwa diplomasi bencana (disaster diplomacy) alam harus dibedakan dengan "kerjasama terkait bencana alam" (disaster-related cooperation). Namun pada prakteknya dua upaya tidak dapat dipisahkan dan saling mendukung. Diplomasi bencana alam berada dalam lingkup khusus sebagai strategi untuk mengkapitalisasi bencana sebagai resource untuk tujuan politik, sosial, dan ekonomi dengan caracara politis. Diplomasi bencana alam dapat dilakukan pemerintah negara, pemerintah daerah, maupun NonGovernmental Organization (NGO). Diplomasi yang dilakukan NGO atau civil society antar negara sering disebut sebagai para-diplomacy, yang sebenarnya cukup signifikan dalam menstimulus kooperasi internasional. Sementara "kerjasama terkait bencana alam" dapat berupa persiapan, mitigasi, respon, dan rekonstruksi dalam kerangka teknis kebencanaan.

Michael M. Glantz melakukan perincian terhadap "kerjasama terkait bencana alam" seperti dalam bentuk keikutsertaan personel pemerintah suatu negara yang membantu negara lain dalam situasi krisis maupun rekonstruksi, maupun secara tidak langsung seperti penyumbangan dana maupun ucapan simpati (M.M. Glantz, 2000: 277-94). Dalam pemahamanan penulis diplomasi bencana alam lebih bersifat politis dan "kerjasama terkait bencana alam" lebih bersifat teknis. Apabila hal teknis ini bermuatan politis maka disebutlah sebagai upaya diplomasi. Dalam pengertian "kerjasama terkait bencana alam" adalah salah satu instrumen penting dalam diplomasi bencana alam, dan dua upaya ini sulit dipisahkan dalam penanganan bencana kontemporer.

Bentuk diplomasi bencana alam sendiri dapat dibedakan dalam diplomasi intra-negara/intrastate dan diplomasi antar negara/interstates. Diplomasi bencana alam intra-negara adalah diplomasi yang melibatkan kelompok-kelompok yang ada dalam satu negara dalam rangka menyelesaikan persoalan atau konflik yang terjadi diantara pihak-pihak tersebut. Salah satu contoh dari diplomasi jenis ini adalah yang terjadi di Afrika Selatan ketika terjadi turbulensi politik dalam negeri pada awal 1990-an terkait gelombang tuntutan demokrasi multi-partai, yang bertepatan dengan kekeringan besar yang melanda selatan Afrika, dapat diinterpretasi dengan baik dengan melakukan diplomasi bencana selama pergantian rezim. Bencana tersebut dapat dikonstruksikan untuk menyatukan seluruh warga Afrika Selatan dengan pemerintah yang menggembar-gemborkan "drought emergency". Bencana kekeringan menjadi arena unjuk gigi bagi rezim yang baru berkuasa untuk menyatukan dan mengambil simpati rakyat.

Bentuk diplomasi bencana alam kedua adalah diplomasi antar negara. Bentuk diplomasi ini lebih variatif dan lebih banyak dikaji akademisi sebagai solusi konflik internasional yang menjanjikan.

Diplomasi bencana alam dalam bentuk ini juga dapat diaplikasikan untuk membangun soft-power bagi suatu negara. Baik diplomasi bencana alam antar negara untuk tujuan resolusi konflik atau untuk membangun soft power, keduanya berada dalam peran sentral pemerintah, namun determinan para-diplomacy sangat diperlukan untuk mendukung terwujudnya tujuan ini. Contoh diplomasi bencana alam ini adalah kasus India-Pakistan, yaitu pada tahun 2005 lalu India dan Pakistan mengalami serangkaian gempa bumi bersamaan di kedua negara, dengan korban jiwa mencapai 7.000 jiwa di Pakistan dan 1.000 di India. 
Bencana gempa bumi ini membuka komunikasi dua negara yang berkonflik di perbatasan daerah Kashmir. Perbatasan kedua negara dibuka untuk jalur pengungsian termasuk Kashmir. Kehangatan terbangun lebih lanjut dalam rekonstruksi bencana yang dilakukan dengan kerjasama. Pembicaraan damai mengenai sengketa Kashmir pun dibuka dengan hangat. Namun sayang diplomasi bencana alam ini belum mampu mewujudkan perdamaian di Kashmir dengan kolapsnya perjanjian damai.

\section{DIPLOMASI BENCANA ALAM DI INDONESIA: PENGALAMAN ACEH DAN YOGYAKARTA}

Indonesia yang secara alamiah memiliki potensi terpapar bencana alam dengan berbagai bentuk dan ancamannya, telah menunjukkan beberapa keberhasilan memanfaatkan bencana alam sebagai sarana kerjasama baik dalam bentuk intra-state maupun inter-state/antar negara dalam menyelesaikan konflik maupun dalam mengembangkan kerjasama antar pihak.

Diplomasi bencana Indonesia berbentuk intra-state yang berhasil dijalankan pemerintah Indonesia contohnya adalah resolusi perdamaian di Aceh. Pada kasus Aceh, diplomasi yang sudah dirintis sebelumnya antara Pemerintah Indonesia dan Gerakan Aceh Merdeka (GAM) untuk mengakhiri konflik terkatalisasi dengan adanya bencana Gempa dan Tsunami Samudera India 2004, dan dibantu banyak pihak internasional termasuk Aceh Monitoring Team (AMM) dan Pemerintah Finlandia. Kerjasama tanggap darurat dan rekontruksi bencana sendiri melibatkan banyak pihak nasional dan internasional, dengan dukungan teknis dan finansial. Konflik antara Gerakan Aceh Merdeka dan Pemerintah Indonesia, telah berlangsung lebih dari 25 tahun, dan untuk menyelesaikan masalah konflik Aceh telah dilakukan upaya perundingan damai semenjak tahun 1995 dengan melibatkan banyak fihak. Namun upaya damai tersebut senantiasa mengalami jalan buntu.

Baru pada perdamaian Helsinki Agustus 2005, konflik antara GAM dan Indonesia mengalami kemajuan yang berarti, di mana perundingan ini terjadi pasca bencana alam gempa bumi dan tsunami di Aceh Desember 2004. Situasi yang kondusif bagi penyelesaian konflik ini tercipta ketika kedua pihak baik GAM maupun pemerintah Indonesia menyadari prioritas penanggulangan dan rekonstruksi akibat bencana gempa dan tsunami Aceh merupakan yang prioritas paling utama. Jatuhnya korban dalam jumlah besar sekitar 180.000 orang tewas, lebih dari 500.000 orang kehilangan tempat tinggal serta rusaknya berbagai infrastruktur utama di Aceh, menjadi pendorong utama dua pihak yang berkonflik untuk kembali ke meja perundingan. Apalagi pasca bencana tsunami, banyak anggota dan simpatisan GAM juga menjadi korban dan kekuatan militer GAM juga semakin melemah pasca tekanan militer pemerintah Indonesia tahun 2003. Selain itu mediator internasional juga menunjukkan kekompakkan untuk memonitor komitmen dua pihak untuk terus melanjutkan proses perundingan. Dalam konteks ini yang perlu mendapat perhatian adalah, bahwa upaya penyelesaian konflik telah ada sebelum bencana tsunami terjadi, namun kemudian menjadi lebih intensif dan masif dalam hal aksi maupun pihak yang terlibat sehingga upaya perdamaian dalam bentuk kesepakatan perdamaian menjadi lebih cepat dicapai.

Sementara diplomasi bencana alam Indonesia dalam bentuk inter-state atau antar negara dalam isu bencana alam yang telah berhasil dilaksanakan adalah berbagai kerjasama yang berhasil dibangun pemerintah pusat, pemerintah daerah maupun NGO dengan berbagai negara atau pihak asing lainnya. Salah satunya adalah yang dilakukan oleh Pemerintah Provinsi Daerah Istimewa Yogyakarta (DIY). DIY sebagai provinsi di Indonesia yang kerap menjadi langganan bencana alam harus bersiap dengan persiapan, mitigasi, respon, dan rekonstruksi bencana alam yang sistematis. Kasus erupsi Gunung Merapi dan Gempa Bumi 2006 menjadi contoh yang menarik sebagai keberhasilan "kerjasama terkait bencana alam" dengan banyak pihak. Kerjasama yang telah berhasil dibangun pasca bencana erupsi Merapi dan Gempa Bumi di Yogyakarta adalah kerjasama Pemerintah Provinsi DIY dengan pemerintah Prefektur Yamanashi Jepang pada 
12 Agustus 2014 (Kedaulatan Rakyat, 13 Agustus 2014). Dua pemerintah daerah tersebut tertarik untuk belajar tentang Kegunungapian, mengingat Prefektur Yamanashi juga memiliki gunung api yang masih aktif dan rawan bencana seperti pemerintah propinsi DIY. Dari inisiasi ini muncul berbagai kerjasama diluar kegunungapian dan penanggulangan bencana seperti budaya dan kerjasama ekonomi.

Keberhasilan ini dapat lebih digemilangkan apabila DIY mampu mengkapitalisasi bencana alam dan menjalin jaringan nasional dan internasional termasuk dalam lingkup kotamadya dan kabupaten untuk riset dan penanganan bencana. Kerjasama sister provinces, twin provinces, sister cities, dan twin cities yang selama ini telah dikelola dengan baik di DIY dapat menjadi jalur diplomasi bencana alam berbasis Pemerintah Provinsi, Pemerintah Kota, dan Pemerintah Kabupaten. Aktivitas para-diplomacy dengan basis NGO dan akademisi juga perlu difasilitasi lebih lanjut untuk mendukung diplomasi bencana alam pada level pemerintah.

Kemudian yang juga penting adalah mitra strategis yang sifatnya simetris juga harus aktif dicari berbagai pihak di DIY terkait diplomasi bencana alam. Sister province dari DIY seperti Negara Bagian California, Perfektur Kyoto, dan Provinsi Chiang Mai menjadi contoh yang baik sebagai mitra strategis DIY dalam diplomasi bencana alam, dikarenakan 3 sister-province ini memiliki kesamaan resiko bencana alam dengan DIY yaitu gempa bumi dan tsunami. Kerjasama riset dan saling bertukar data terkait penanganan bencana menjadi penting dan saling menguntungkan.

Sementara itu perasaan sepenanggunggan juga dapat menjadi katalis kerjasama intensif di bidang lain. Aktivitas para-diplomacy yang akan saling mendukung diplomasi bencana alam juga patut disoroti. Kerjasama apik antara UGM dengan Kyoto University dan Chiang Mai University sebagai universitas di sister province milik DIY ini juga akan banyak berperan dalam diplomasi bencana alam yang diinisiasi DIY. Universitas dapat menjadi wadah riset bersama termasuk pertukaran data yang akan sangat signifikan berperan. Aktivitas paradiplomacy seperti ini penting didukung karena sifatnya yang terbukti efektif, murah, dan sedikit menimbulkan biaya politik.

Selain kerjasama antara pemerintah, hal lain yang menarik adalah peran serta $\mathrm{NGO}$ dalam pengembangan kerjasama. Misalnya adalah organisasi sosial keagamaan seperti Muhammadiyah yang memiliki Majlis yang memiliki peran khusus dalam issue kebencanaan, yakni Muhammadiyah Disaster Management Center (MDMC). MDMC membangun dan melanjutkan kerjasama Internasional yang telah terbangun sejak momentum Tsunami Aceh 2004 secara langsung dengan berbagai lembaga atas nama Muhammadiyah dalam bidang-bidang:

a. Pelayanan Kesehatan Bencana: Direct Relief International, CRS, TAF, JICA, Belgium, Mercy Relief, USAID, AUSAID

b. Pendidikan Pasca Bencana: WVI, AUSAID, Mercy Relief

c. Pusat Kegiatan Anak di area Bencana (Secured Area): UNICEF, YOTS, Save the Children

d. Penguatan Komunitas Pasca Bencana dan Pembangunan Tenpat Ibadah: WON Buddhism, TAF, UEA, KSA

e. Trauma Counseling: Mercy Relief, Capacitar International

f. Water Suplay and Sanitation: AUSAID, IRD

g. Emergency Logistic: DRI, Libya, IOM

h. Livelihood: WVI, GIve 2 Asia, AUSAID

i. Women Program: UNIFEM, UNDP, Give 3 Asia

j. Sekolah dan Komunitas Siaga Bencana: AUSAID

k. Kesiapsiagaan Rumah Sakit dan Komunitas: AUSAID, Direct Relief International

1. Penguatan Kompetensi: HOPE, US Pacific Comand, ADPC, ICRC ${ }^{1}$

Dari sini tercermin bahwa Muhammadiyah memandang perlu melakukan kerjasama internasional dengan berbagai fihak untuk kepentingan pencegahan dan pengurangan dampak bencana alam pada satu sisi, dan pada sisi lain mempergunakan issue kebencanaan untuk membangun kerjasama internasional bagi peningkatan kesejahteraan masyarakat secara luas. 


\section{KESIMPULAN}

Studi terkini tentang isu bencana alam menunjukkan bahwa bencana alam yang semula dipahami sebagai fenomena negatif, dapat mengalami pergeseran makna bahwa bencana tidak sepenuhnya destruktif. Ada beberapa manfaat yang dapat ditarik dari terjadinya bencana alam, apabila dikelola dengan pemahaman dan perangkat yang tepat, bahkan bencana ini dapat dikapitalisasi lebih lanjut dalam bentuk disaster diplomacy.

Studi diplomasi bencana memaknai bencana sebagai sebuah instrumen yang penting untuk memperjuangkan kepentingan politik seperti perdamaian, kepentingan ekonomi seperti kolaborasi kerjasama ekonomi antar negara secara lebih intensif, atau kepentingan sosial budaya untuk membangun komunitas humanis dan berkeadaban. Fenomena bencana alam jika difahami dalam perspektif positif, justru dapat memberikan nilai tambah yang sangat besar untuk menyelesaikan berbagai problem kemanusian yang selama ini tak terpecahkan melalui diplomasi politik maupun ekonomi yang seringkali berwatak distributif, menang dan kalah. Melalui pengalaman Indonesia, diplomasi bencana dapat digunakan untuk menyelesaikan konflik yang berlarutlarut. Selain itu diplomasi bencana juga dapat digunakan untuk mengembangkan kerjasama internasional lainnya seperti sister city, sister province dll. Dengan catatan bahwa seringkali diplomasi bencana berperan sebagai trigger dan tidak dapat berjalan sendiri dalam penyelesaian konflik. Diplomasi bencana dapat bekerja efektif jika bekerja simultan dengan mekanisme yang lain.

\section{REFERENSI}

Bappenas, Hasil Analisa Sistem Penanggulangan Bencana, Bappenas, Jakarta, 2007

B. Chamsyah, Mainstreaming Disaster Risk Reduction in National Policies and Programmes: An Overview of National Action Plan for Disaster Risk Reduction in Indonesia, Disampaikan pada 2nd Asian Ministerial Conference on Disaster Risk Reduction 7-8 November 2007, New Delhi, India

Comfort, L.K \& J. Holland, "Disaster: Agent of Diplomacy or Change in International Affairs?", Cambridge Review of International Affairs, 14 No. 1 (2000)

Glantz, M.M., "Climate Related Disaster Diplomacy: A US-Cuban Case
Study", Cambridge Review of International Affairs, Autumn-

Winter, Vol. XIV No. 1, 2000

http://www.mdmc.or.id/index.php/kerjasama\#sthash.CCxua5DD.dpuf Kelman, I 'Disaster diplomacy: Can tragedy help build bridges among countries?', UCAR Quarterly, Fall 2007 , 'Illan Kelman on Disaster Diplomacy', Five Books (daring),

$<$ http://fivebooks.com/interviews/ilan-kelman-on-disaster-

diplomacy?print=\#> , ,'Wave of peace? Tsunami disaster diplomacy in Aceh, Indonesia', Geoforum, 39 (1), 2008 ,"Disaster diplomacy: Can tragedy help build bridges among countries?"

, "Acting on Disaster Diplomacy", Journal of International Affairs; Spring 2006; 59, 2

Kedaulatan Rakyat, 13 Agustus 2014

Nye, J. S. The Power to Lead. Oxford University Press, New York, 2008

UN-ISDR Informs, Disaster Diplomacy in the Asia-Pacific Region, UNISDR, Bangkok, 2007

ESCAP, The Asia Pacific Disaster Report, 2010: Protecting Development Gains, UN-ISDR

Snyder, A.J. Is There a Silver Lining? Long-term Changes in International Cooperation Levels After a Natural Disaster, The University of Georgia, 2008 